\title{
IPSILATERAL SUPPRESSION OF TRANSIENT EVOKED OTOACOUSTIC EMISSIONS IN ADULTS
}

\author{
Joseph Kei, Amanda-Mei Fullerton, Beatrice Smith, Lisa Henderson, Alison Collins, \\ Joanna Smith, Wayne Wilson
}

Division of Audiology, School of Health and Rehabilitation Sciences, University of Queensland, Brisbane, Australia

Corresponding author: Joseph Kei, Division of Audiology, School of Health and Rehabilitation Sciences, University of Queensland, Brisbane, QLD 4072, Australia, e-mail: k.kei@uq.edu.au

\begin{abstract}
Background: Measurement of the medial olivocochlear (MOC) reflex provides useful clinical information for understanding the function of the auditory system. Although transient evoked otoacoustic emission (TEOAE) suppression has been demonstrated to be an indicator of MOC activity, its full role and fine details of TEOAE suppression spectra are still not clear. The aim of this study was to investigate details of ipsilateral suppression of TEOAEs in normally hearing adults.

Material and methods: Exactly 29 adults (13 males, 16 females, mean age 26.5 years, range 18-42 years), who passed a battery of tests including otoscopy, pure tone audiometry, immittance, and TEOAE tests, participated in the study. Suppression was evaluated by comparing TEOAEs obtained with and without an ipsilateral suppressor in a forward-masking paradigm.

Results: In general, suppression was small - less than $1.4 \mathrm{~dB}$ at all frequencies studied. The spectrum of mean TEOAE suppression showed suppression was greatest between 586 and $3711 \mathrm{~Hz}(0.6-1.4 \mathrm{~dB})$ but less than $0.6 \mathrm{~dB}$ between 3906 and $4883 \mathrm{~Hz}$. Mean suppression increased with post-stimulus time from $0.1 \mathrm{~dB}$ in the $2-4 \mathrm{~ms}$ time window to a maximum of $2.26 \mathrm{~dB}$ in the 16-18 ms window; the mean suppression between 8 and $18 \mathrm{~ms}$ after noise stimulation was $1.32 \mathrm{~dB}$ ( $\mathrm{range}=0.22-3.23 \mathrm{~dB}$ ). There were no significant gender or ear-laterality effects. Noise levels as measured in the ear canal were found to have a significant effect on calculated suppression at some frequencies.
\end{abstract}

Conclusions: The present study provides evidence of small ipsilateral TEOAE suppression by forward-masking noise in normally hearing adults. However, care is needed in interpreting the findings as noise in the ear canal can be a confounding factor during measurement of TEOAE suppression.

Key words: otoacoustic emissions $\bullet$ medial olivocochlear reflex $\bullet$ suppression

\section{SUPRESIÓN IPSILATERAL DE EMISIONES OTOACÚSTICAS PROVOCADAS POR EL RUIDO EN ADULTOS}

\section{Resumen}

Bases teóricas: La medición del reflejo olivo-coclear nos aporta importantes datos clínicos sobre el papel del sistema auditivo. Aunque se haya probado que la supresión de las emisiones otoacústicas provocadas por el ruido (TEOAE) demuestra la actividad de la parte medial del sistema olivo-coclear (MOC), sigue sin conocerse plenamente la importancia de este reflejo ni su característica espectral detallada. El objetivo del estudio descrito en las páginas de este artículo ha sido el de explorar el efecto ipsilateral de la supresión TEOAE en adultos con audición correcta.

Métodos y herramientas de investigación: En el estudio con la batería de pruebas han participado 29 adultos (13 hombres, 16 mujeres de la edad media de 26,5, del grupo de edad de 18-42). Las pruebas comprendían: otoscopia, audiometría tonal, audiometría de impedancia y la medición TEOAE. La supresión ha sido valorada comparando los resultados de los TEOAE medidos tanto durante la administración del supresor ipsilateral como y cuando dicho supresor no se administraba.

Resultados: En términos generales, la supresión del ruido ha sido pequeña- menos de 1,4 dB en todas las frecuencias estudiadas. La supresión de TEOAE ha sido la más alta en el rango de 586-3711 Hz (es decir, 0,6-1,4 dB); a su vez, en el rango de $3906-4883 \mathrm{~Hz}$ ha sido menos de $0,6 \mathrm{~dB}$. El nivel medio de la supresión crecía con el tiempo después del estímulo desde 0,1 dB para la ventana de 2-4 ms, hasta máximo 2,26 dB en la ventana 16-18 ms. El valor medio de la supresión en el tiempo de 8-18 ms tras la administración del ruido, ha sido de 1,32 dB (rango entre 0,22 y 3,23 dB). No se han observado diferencias considerables entre ambos sexos y entre las orejas. Sin embargo, se ha observado el impacto significativo del ruido en el conducto auditivo en el importe de la supresión en determinadas frecuencias. 
Conclusiones: Estos estudios demuestran que el efecto de la supresión ipsilateral TEOAE por el ruido antes administrado es pequeño. Sin embargo, estos datos recibidos en la prueba deben interpretarse con cierta precaución, dado que la presencia del ruido en el conducto auditivo puede ser factor que interfiera la medición de la supresión TEOAE.

Palabras clave: emisiones otoacústicas • reflejo olivo-coclear • supresión

\section{ИПСИЛАТЕРАЛЬНАЯ СУПРЕССИЯ ОТОАКУСТИЧЕСКОЙ ЭМИССИ, ВЫЗВАННОЙ ШУМОМ У ВЗРОСЛЫХ}

\section{Изложение}

Теоретические основания: Измерение оливо-кохлеарного рефлекса предоставляет важные клинические данные относительно роли слуховой системы. Хотя уже доказано, что супрессия отоакустической эмисси, вызванной шумом (TEOAЕ) указывает на активность медиальной части оливо-кохлеарной системы (МОС), все еще значение этого рефлекса, а также его точная спектральная характеристика не до конца известны. Исследование, описываемое в настоящей статье, имело целью углубить ипсилатеральный эффект супрессии ТЕОАЕ у взрослых с хорошим слухом.

Методы и инструменты анализа: Объектом исследований с использованием батареи тестов являлось 29 взрослых человек (в том числе 13 мужчин и 16 женщин,,средняя возраста - 26 с половиной лет, возрастные рамки 18-42 года). Исследования включали: отоскопию, тональную аудиометрию, импендантную аудиометрию, а также измерение TЕОАЕ. Супрессия была оценена, сравнивая результаты ТЕОАЕ, измеренные в ходе подачи ипсилатерального супрессора, а также тогда, когда супрессор не был применен.

Результаты: В общем, заглушение было небольшое - ниже 1,4 дБ во всех иследованных частотах. Супрессия ТЕОАЕ являлась самой большой в пределе 586-3711 Гц (т.е. 0,6-1,4 дБ), тогда как в пределе 3906-4883 Hz она была меньше 0,6 дБ. Средний уровень супрессии со временем после импульса рос от 0,1 дБ для окошка 2-4 мс до максимально 2,26 дБ в окошке 16-18 мс. Среднее значение заглушения во время 8-18 мс после подачи шума было 1,32 дБ (предел 0,22-3,23 дБ). Существенных межполовых или межушных разниц не зафиксировано. Однако наблюдалось значительное влияние интенсивности шума в слуховом проходе на значения заглушения на определенных частотах.

Итоги: Настоящие исследования доказывают, что эффект ипсилатеральной супрессии ТЕОАЕ с использованием предварительно доставляемого шума является небольшим. Однако же полученные данные следует интерпретировать с определенной долей осторожности, потому что наличие шума в слуховом проходе может быть фактором, нарушающим измерение супрессии TEOAE.

Ключевые слова: отоакустические эмиссии • оливо-кохлеарный рефлекс • супрессия

\section{IPSILATERALNA SUPRESJA EMISJI OTOAKUSTYCZNYCH WYWOŁANYCH TRZASKIEM U OSÓB DOROSŁYCH}

\section{Streszczenie}

Podstawy teoretyczne: Pomiar odruchu oliwkowo-ślimakowego dostarcza ważnych danych klinicznych o roli układu słuchowego. Choć udowodniono, że supresja emisji otoakustycznych wywołanych trzaskiem (TEOAE) wskazuje na aktywność części medialnej systemu oliwkowo-ślimakow-ego (MOC), wciąż nie jest w pełni znane znaczenie tego odruchu ani jego dokładna charakterystyka spektralna. Badanie opisywane na łamach niniejszego artykułu miało na celu zgłębienie ipsilateralnego efektu supresji TEOAE u dorosłych o prawidłowym słuchu.

Metody i narzędzia badawcze: Badaniom przy użyciu baterii testów poddano 29 osób dorosłych (w tym 13 mężczyzn, 16 kobiet w średnim wieku 26,5 lat z przedziału wiekowego 18-42). Zawierała ona: otoskopię, audiometrię tonalną, audiometrię impedancyjną oraz pomiar TEOAE. Supresję oceniono, porównując wyniki TEOAE zmierzonych w trakcie podawania ipsilateralnego supresora i gdy supresor nie był podawany.

Wyniki: W ogólnym zarysie, tłumienie było niewielkie - poniżej 1,4 dB we wszystkich badanych częstotliwościach. Supresja TEOAE była największa w przedziale $586-3711 \mathrm{~Hz}$ (tj. 0,6-1,4 dB), natomiast w przedziale 3906-4883 $\mathrm{Hz}$ wynosiła mniej niż $0,6 \mathrm{~dB}$. Średni poziom supresji wzrastał wraz z czasem po bodźcu od $0,1 \mathrm{~dB}$ dla okna $2-4 \mathrm{~ms}$ do maksymalnie $2,26 \mathrm{~dB}$ w oknie 16-18 ms. Średnia wartość tłumienia w czasie 8-18 ms po podaniu szumu wynosiła 1,32 dB (przedział 0,22-3,23 dB). 
Nie odnotowano istotnych różnic międzypłciowych lub międzyusznych. Zaobserwowano natomiast znaczący wpływ natężenia szumu w przewodzie słuchowym na wartości tłumienia w określonych częstotliwościach.

Wnioski: Niniejsze badania dowodzą, że efekt ipsilateralnego supresji TEOAE przez szum podawany poprzedzająco jest niewielki. Niemniej jednak, uzyskane dane należy interpretować z pewną dozą ostrożności, ponieważ obecność szumu w przewodzie słuchowym może być czynnikiem zakłócającym pomiar supresji TEOAE.

Słowa kluczowe: emisje otoakustyczne • odruch oliwkowo-ślimakowy • supresja

\section{Background}

Transient evoked otoacoustic emissions (TEOAEs) are low-level sounds produced by the cochlea in response to acoustic stimulation [1]. The mechanisms for producing TEOAEs are thought to be a combination of reflections from random perturbations along the basilar membrane and reverse transmission induced by distortion caused by the stimuli [2-4]. The energy for these reflection and distortion mechanisms comes from the cochlear amplifier associated with active motile activity of the outer hair cells (OHCs) and biomechanical movements of the stereocilia within the organ of Corti of a healthy cochlea [2].

Motility of OHCs can be modified by activation of the olivocochlear efferent system, resulting in a reduction in otoacoustic emission (OAE) amplitude. More specifically, the thick myelinated medial olivocochlear (MOC) fibres innervate the OHCs, forming a MOC reflex (see [5] for review). This is not to be confused with the middle ear muscle reflex (MEMR) which elicits contraction of the stapedius muscle, resulting in a reduction of sound travelling through the middle ear. The MEMR can be distinguished from the MOC reflex in terms of its higher operational stimulus level and delayed response to acoustic stimuli of 25-250 ms compared to the MOC reflex response time of 8-10 ms [6]. Based on an animal model, Guinan [5] depicted the ipsilateral MOC reflex pathway as follows: suppressor stimuli to the ipsilateral cochlea excite auditory nerve fibres, which innervate reflex interneurons in the posteroventral cochlear nucleus; axons of these cochlear-nucleus interneurons cross the brainstem ventrally to innervate MOC neurons on the contralateral side; contralateral MOC neurons then project to the ipsilateral cochlea in the crossed olivocochlear bundle. The contralateral MOC reflex pathway takes a different route (see [5]). Guinan points out that while the contralateral reflex crosses in the trapezoid body and uses uncrossed MOC fibres, the ipsilateral reflex is a double-crossed reflex with crossings in the trapezoid body and in the crossed MOC fibres [5].

To date, most research has focused on measuring the MOC reflex by contralateral stimulation [7-11]. The contralateral protocol involves presenting a stimulus such as a click to the test ear while a suppressor noise is presented simultaneously to the contralateral ear. The main advantage of contralateral suppression is that the stimulus and the suppressor are separate, thus facilitating the measurement of OAEs and avoiding acoustic interaction. In contrast, the ipsilateral stimulation protocol involves delivering an OAEeliciting stimulus and a suppressor noise to the same ear. This method presents challenges in separating the two. To overcome these problems, Berlin et al. [12] introduced a forward-masking paradigm, in which the suppressor was presented before the click stimulus.

Eliciting the MOC reflex ipsilaterally does offer some advantages over contralateral stimulation. First, the ipsilateral MOC reflex involves two crossed pathways of the olivocochlear bundle, while the contralateral MOC reflex pathway involves the uncrossed olivocochlear bundle only [5]. Second, the results obtained from ipsilateral testing are not influenced by afferent or efferent disorders that affect the contralateral ear. Third, TEOAE suppression obtained by ipsilateral stimulation may be greater than that by contralateral stimulation. Hood et al. [13] obtained mean TEOAE suppression of 2.4 and $1.5 \mathrm{~dB}$ in normal hearing adults by ipsilateral and contralateral stimulation, respectively.

Presently, there are a limited number of studies which have evaluated the MOC reflex in adults by measuring the ipsilateral suppression of TEOAEs using a forward-masking paradigm. The exploratory study of Berlin et al. [12] investigated the effects of various test parameters on TEOAE suppression in seven normally hearing adults, comparing TEOAE suppression obtained by binaural, ipsilateral, and contralateral stimulation. Using bilateral, ipsilateral, and contralateral suppressors (white noise for $408 \mathrm{~ms}$, silence for $10 \mathrm{~ms}$, and then a click), Berlin and colleagues obtained a root-mean-squared (RMS) mean suppression amplitude across a time-window of $8-18 \mathrm{~ms}$ of $1.6,0.9$, and $0.5 \mathrm{~dB}$, respectively.

The MOC reflex provides useful clinical information for understanding the auditory system and auditory disorders. Studies have reported reduced or no suppression of OAEs in patients with auditory neuropathy spectrum disorders (ANSD) [13], auditory processing disorders [14], unilateral acoustic neuroma with measurable OAEs [15], space-occupying lesions in the superior olivary complex of the brainstem [16], and unilateral tinnitus [17]. Individuals with hyperacusis may show large TEOAE suppression in the affected ear [18].

Hood et al. [13] compared TEOAE suppression obtained from nine patients with bilateral ANSD and normally hearing adults matched for age and gender. As suppressor, $400 \mathrm{~ms}$ of wideband noise was presented either binaurally, ipsilaterally, or contralaterally in a forward-masking paradigm (again, $10 \mathrm{~ms}$ of silence separated the noise from the linear clicks). Results showed significantly different mean TEOAE suppression between the two groups for all stimulation conditions $(p<0.003)$. For the ANSD group, mean suppression in the post-stimulus time window of $8-18$ ms was $0.22 \mathrm{~dB}$ across all stimulation conditions. For the control group, the corresponding mean 
suppression amplitudes (for right and left ears) were 4.57 and $4.37 \mathrm{~dB}$ (binaural), 2.67 and $2.15 \mathrm{~dB}$ (ipsilateral), and 1.65 and $1.39 \mathrm{~dB}$ (contralateral), respectively. No significant differences in suppression were observed between the right and left ears $(p>0.05)$. In the same study, Hood and colleagues also studied TEOAE suppression in a patient with ANSD in the left ear only. TEOAEs were measured using the same test procedure under the three test conditions. The results indicated absence of suppression in the right-ear-contralateral and left-ear-ipsilateral noise conditions (i.e., noise in the left ear), indicating a deficit in afferent function in the left ear.

In summary, the evidence of TEOAE suppression and its link to the MOC system have highlighted the importance of further understanding the function of the efferent auditory system. Although in previous studies TEO$\mathrm{AE}$ suppression has proven to be an indicator of MOC activity, its full role and details of the TEOAE suppression spectrum are still not clear [10]. There are many different protocols to assess suppression, and as yet there is no agreement on what constitutes an appropriate protocol to produce optimal results. There is also a lack of consensus on the amount of suppression considered normal in normally hearing adults. Findings from studies of ipsilateral suppression of TEOAEs in normally hearing adults range from $0.5-1 \mathrm{~dB}$ [12] to $2-4 \mathrm{~dB}$ [13]. Such variations can be attributed to subject differences, test protocols, and small sample sizes $(<10)$. Normal TEOAE suppression levels in healthy subjects still need to be established before they can be used in clinical tests of the MOC system. To date, the effects of gender and ear laterality on TEOAE suppression have not been systematically investigated. To help fill this gap, the present study aims to investigate the characteristics of ipsilateral suppression of TEOAEs obtained from a sample of normally hearing adults using a forward-masking paradigm.

\section{Material and methods}

\section{Participants}

Initially, 30 adults were recruited from students of the University of Queensland and their associates. Recruitment and consent was conducted in accordance with ethical guidelines prescribed by the Behavioural and Social Sciences Ethical Review Committee of the University of Queensland. Participants reported no history of significant noise exposure or middle ear infection. In addition, participants were required to pass an initial test battery consisting of otoscopy, pure tone audiometry, immittance, and TEOAE (pass criteria described in the next section). One subject was excluded for failing to meet the selection criteria, leaving 29 adults ( 13 males, 16 females). Their mean age was 26.5 years (SD 5.9 years, range $18-42$ years).

\section{Procedure}

Testing was conducted in a sound-treated room at the University of Queensland Audiology Clinic with an average ambient noise level of less than $35 \mathrm{dBA}$ as measured with a CSL-254 sound level meter. Testing was undertaken by Masters of Audiology students with training in audiometric testing and TEOAE measurement. One ear per participant was assessed. Otoscopic examination was first performed to identify any contraindications such as obstruction or abnormal tympanic membrane. Pure tone audiometry was conducted with a GSI 61 clinical audiometer. All participants had air conduction thresholds less than or equal to $20 \mathrm{~dB} \mathrm{HL}$ at $0.25,0.5,1,2,3$, and $4 \mathrm{kHz}$ in the test ear. Immittance testing was performed using a Madsen Zodiac 901 tympanometer to determine middle ear status. All participants had Type A tympanograms with a tympanometric peak pressure of 50 to $-100 \mathrm{daPa}$, static compliance of $0.3-1.6 \mathrm{~mL}$, and ear canal volume of 0.9 to $1.8 \mathrm{~mL}$ [19]. Ipsilateral acoustic stapedial reflexes to 1 and $2 \mathrm{kHz}$ pure tone stimulations were observed at or below $95 \mathrm{~dB}$ HL [20].

All TEOAE tests were performed using an ILO88 Otodynamics Analyser (ver. 5.6Y). Calibration of the probe was performed weekly or as necessary according to the manufacturer's specifications. To ensure adequate emissions could be obtained, a conventional TEOAE test was performed using the Quickscreen protocol (which was found to produce more robust TEOAEs than the default protocol [21]). The pass criterion was a $3 \mathrm{~dB}$ signal-to-noise ratio (SNR) in at least four of five half-octave frequency bands centred at $1,1.5,2,3$, and $4 \mathrm{kHz}[21]$.

After passing the conventional TEOAE test, the participant was assessed using a special protocol for TEOAE suppression available from the ILO88 Otodynamics Analyser. TEOAEs were evoked using linear clicks at an intensity level of $65 \mathrm{~dB}$ peak sound pressure level (pkSPL) with and without broadband noise (BBN). The stimulus intensity was based on previous studies which have demonstrated greater suppression effects for lower rather than higher intensity stimulus levels [9,17]; this level also maximises suppression while minimising the MEMR. Linear clicks (of the same polarity) were used in order to avoid distortions in response amplitude $[9,12,22]$. The recording window following the click stimulus onset was set at $20.5 \mathrm{~ms}$, as most suppression has previously been observed 8-18 ms after the click $[6,22]$. Averaging was done for 100 sweeps, with each sweep containing four stimuli, giving a total average of 400 stimuli. The suppressor noise, 400 $\mathrm{ms}$ long, was presented ipsilaterally at $65 \mathrm{~dB}$ SPL in a forward-masking paradigm (i.e., BBN preceded the clicks), with $10 \mathrm{~ms}$ of silence separating the offset of noise from the onset of the first click). Figure 1 illustrates the testing and recording paradigms. A noise duration of $400 \mathrm{~ms}$ was used because Hood et al. [23] found that the magnitude of suppression increased with the duration of the suppressor up to $400 \mathrm{~ms}$. For each participant, TEOAE suppression was measured as the difference between an initial recording done with no suppressor noise and a second recording with suppressor noise; the sequence was repeated and then saved to a computer for analysis.

\section{Data analysis}

The TEOAE suppression data was initially analyzed using the Kresge EchoMaster (v.4) program [24] to quantify TEOAE amplitude, repeatability of the responses without suppressor, and suppression effects across frequency and time windows [25]. Each of the four TEOAE recordings was required to have a minimum SNR of $3 \mathrm{~dB}$. To 


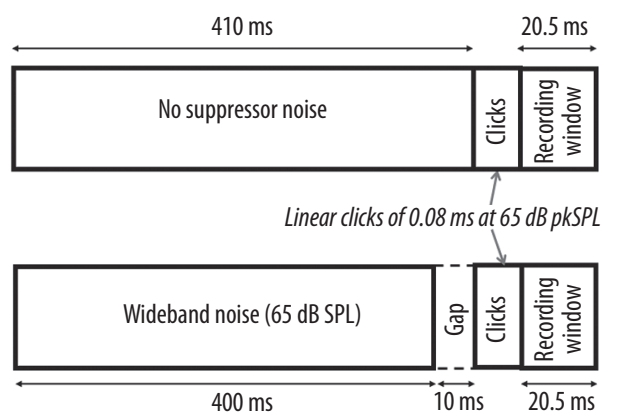

Figure 1. Paradigms for measuring TEOAE suppression. The top panel shows the baseline condition, a quiet period of $410 \mathrm{~ms}$ followed by 4 linear clicks of $0.08 \mathrm{~ms}$ at 65 $\mathrm{dB}$ pkSPL and a recording window of $20.5 \mathrm{~ms}$. The lower panel shows the suppression condition, $400 \mathrm{~ms}$ of suppressor noise of $65 \mathrm{~dB} \mathrm{SPL}$ and a gap of $10 \mathrm{~ms}$, followed by the same 4 linear clicks of $0.08 \mathrm{~ms}$ at $65 \mathrm{~dB}$ pkSPL and a recording window of $20.5 \mathrm{~ms}$. Suppression is calculated as the difference between the two conditions

ensure repeatability of the two replications within each of the with- and without-noise conditions, the cross-correlation between them was required to be at least 0.7 . When these conditions were met, the two replications within each of the with- and without-noise conditions were averaged. Suppression was determined by subtracting the averaged TEOAE response in the with-noise condition from that in the without-noise condition. Responses were analyzed in a time window of 3-20.5 ms after click stimulus offset and in the time range of 8 to $18 \mathrm{~ms}$, as previous studies have consistently shown maximal suppression effects occurring between 8 and $18 \mathrm{~ms}[9,12,22]$. TEOAE responses were then Fourier analysed at frequencies between 586 and $4883 \mathrm{~Hz}$. Responses outside this frequency range were excluded from analysis because they were usually small, variable, or contaminated with noise.

\section{Results}

\section{TEOAE suppression across frequency}

TEOAE data from each participant were analysed as a function of time and frequency. Figure 2 shows an example of the results of TEOAE suppression obtained from the right ear of one of the participants (a 33-year-old female). The differences across time between the withoutnoise (A) and with-noise (B) conditions are shown in the lower portion of Figure 2. Here the cursors are adjusted to highlight the time period between 8 and $18 \mathrm{~ms}$, and the average suppression across this interval is $2.02 \mathrm{~dB}$. The corresponding frequency domain differences are shown in the upper portion of Figure 2. It is clear there is a consistent decrease in spectral amplitude for the suppressorpresent condition.

Table 1 shows a summary of TEOAE responses obtained from the 29 participants with and without suppression. In the unsuppressed (without-noise) condition (A), the mean amplitude gradually increased from $-10.0 \mathrm{~dB}$ at 586 $\mathrm{Hz}$ to a maximum of $-2.7 \mathrm{~dB}$ at $1172 \mathrm{~Hz}$, and then decreased to $-8.4 \mathrm{~dB}$ at $2734 \mathrm{~Hz}$, finally decreasing rapidly

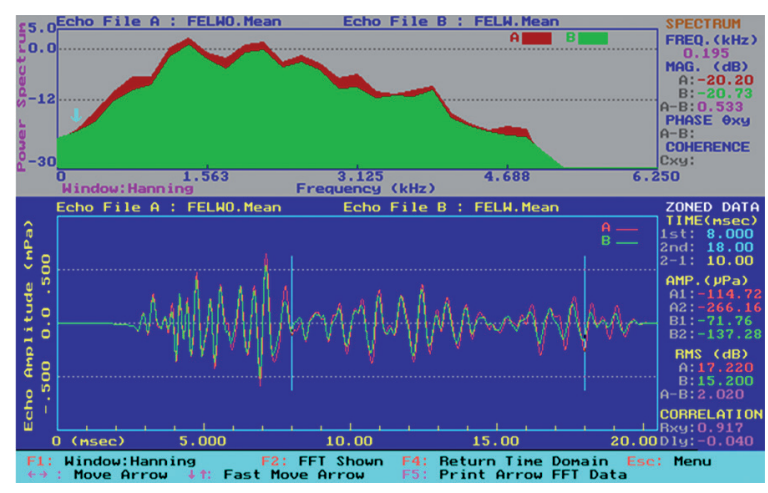

Figure 2. Example of suppression obtained using ipsilateral noise presented in a forward-masking paradigm to one participant (a 33-year-old female with normal auditory function). In the time domain (bottom), the unsuppressed condition is shown as the red trace and the suppressed condition in green. The cursors highlight the region between 8 and $18 \mathrm{~ms}$, where average suppression is calculated to be $2.02 \mathrm{~dB}$. In the frequency domain (top), suppression is shown as the gap between the two colours

to $-24.4 \mathrm{~dB}$ at $4883 \mathrm{~Hz}$. Despite the small mean amplitudes there was a consistent small suppression of about $1 \mathrm{~dB}$ and the standard deviations remained relatively constant at 5-6 dB. The overall pattern of the group results is comparable to those obtained from the individual whose results are shown in Figure 2.

To compare TEOAE amplitudes between the without-noise and with-noise conditions, an analysis of variance (ANOVA) was applied to the data with TEOAE amplitude as the dependent variable, and condition (A/B), frequency (23 frequencies), ear (left/right), and gender as independent variables. An alpha level of 0.05 was used for all analyses. The Greenhouse and Geisser (G-G) [26] approach was used to compensate for violation of compound symmetry and sphericity. The ANOVA results showed a significant condition effect $[F(25,1)=83.636, p<0.0001)$, significant frequency effect $[F(25,22)=96.885, p<0.0001]$, and a significant Condition $\times$ Frequency interaction $[F(191.4$, $22)=2.568, p=0.012]$. All other main effects and their interactions did not reach significance $(p>0.05)$.

The condition effect was further investigated using a paired samples $t$-test with Bonferroni adjustment. The results showed that the TEOAE amplitudes for the without-noise condition were significantly greater than those for the with-noise condition at $781,977,1172,1367,1563,1758$, $1953,2148,2344,2539,2734,2930,3125,3320,3516$, and $3711 \mathrm{~Hz}(p<0.002)$. The Condition $\times$ Frequency interaction indicates that the pattern of TEOAE amplitudes obtained under the without-noise condition was different from that obtained under the with-noise condition across the frequencies.

In view of the significant frequency effect, a post hoc multiple comparisons test with Bonferroni adjustment was performed. The results, shown in Table 2, indicate significant differences in TEOAE amplitude across frequencies. In particular, the pattern of results indicated a significant 
Table 1. Mean amplitudes and standard deviations of TEOAE responses obtained from 29 normally hearing adults under the without-noise (A) and with-noise (B) conditions

\begin{tabular}{|c|c|c|c|c|}
\hline $\begin{array}{l}\text { Frequency } \\
\quad(\mathrm{Hz})\end{array}$ & $\begin{array}{c}\text { A: mean amplitude } \\
(\mathrm{dB})\end{array}$ & $\begin{array}{c}\text { A: standard deviation } \\
\text { (dB) }\end{array}$ & $\begin{array}{l}\text { B: mean amplitude } \\
\text { (dB) }\end{array}$ & $\begin{array}{l}\text { B: standard deviation } \\
\text { (dB) }\end{array}$ \\
\hline 586 & -10.02 & 3.52 & -10.95 & 3.89 \\
\hline 781 & -5.67 & 4.29 & -7.04 & 4.49 \\
\hline 977 & -3.43 & 4.40 & -4.74 & 4.28 \\
\hline 1172 & -2.66 & 4.35 & -3.78 & 4.22 \\
\hline 1367 & -3.40 & 4.89 & -4.40 & 5.01 \\
\hline 1563 & -4.40 & 5.21 & -5.32 & 5.21 \\
\hline 1758 & -6.89 & 4.75 & -8.03 & 4.79 \\
\hline 1953 & -7.26 & 5.53 & -8.46 & 5.52 \\
\hline 2148 & -6.97 & 6.48 & -7.86 & 6.38 \\
\hline 2344 & -6.93 & 5.61 & -7.49 & 5.55 \\
\hline 2539 & -6.98 & 5.65 & -7.64 & 5.65 \\
\hline 2734 & -8.37 & 5.03 & -9.06 & 4.79 \\
\hline 2930 & -10.03 & 5.19 & -10.91 & 4.84 \\
\hline 3125 & -12.34 & 5.18 & -13.05 & 4.84 \\
\hline 3320 & -14.71 & 4.85 & -15.66 & 5.15 \\
\hline 3516 & -16.49 & 5.49 & -17.45 & 5.68 \\
\hline 3711 & -18.26 & 5.66 & -19.40 & 6.09 \\
\hline 3906 & -19.05 & 6.04 & -19.54 & 5.74 \\
\hline 4102 & -19.19 & 6.08 & -19.73 & 5.83 \\
\hline 4297 & -21.52 & 5.41 & -22.05 & 5.41 \\
\hline 4492 & -22.66 & 4.93 & -23.05 & 4.72 \\
\hline 4688 & -23.73 & 5.68 & -23.81 & 5.13 \\
\hline 4883 & -24.37 & 4.99 & -24.86 & 4.99 \\
\hline
\end{tabular}

decrease in amplitude as the frequency increased from 2930 to $4883 \mathrm{~Hz}$.

The significant difference in TEOAE amplitude between the without-noise and with-noise conditions characterizes the suppression effect (A-B) due to noise. Figure 3 presents the mean suppression and standard deviation at 23 tested frequencies. Mean suppressions were greater than $0.56 \mathrm{~dB}$ from 586 to $3711 \mathrm{~Hz}$, with three noticeable peaks of $1.37,1.19$, and $1.14 \mathrm{~dB}$ at 781,1953 , and $3711 \mathrm{~Hz}$, respectively. The mean suppression reached as low as 0.08 $\mathrm{dB}$ at $4688 \mathrm{~Hz}$.

To compare suppression across frequencies, an ANOVA with repeated measures was applied to the data with suppression $(\mathrm{A}-\mathrm{B})$ as the dependent variable, and frequency (23 frequencies), ear (left/right), and gender as independent variables. To compensate for violation of compound symmetry and sphericity, the G-G approach was again used. The results showed a significant frequency effect
$[F(7.7,191.4)=2.568, p=0.012]$. None of the other main effects and interactions reached significance $(p>0.05)$.

In view of the significant frequency effect, a post hoc multiple comparisons test with Bonferroni adjustment was performed. The results showed significant differences in TEOAE amplitude between 781 and $4688 \mathrm{~Hz}$ only $(p=0.025)$. None of the other comparisons reached significance $(p>0.05)$.

\section{TEOAE suppression across time}

When the Kresge EchoMaster Program was set to analyze data in the time domain, suppression level was found to depend on time, with maximum suppression occurring at $8-18 \mathrm{~ms}$ after the click stimulus $[6,22]$. In the present study, the suppression (A-B) during the $8-18 \mathrm{~ms}$ window was measured for all participants, but due to a computer problem data could only be retrieved for 19 of them (11 F and $8 \mathrm{M} ; 10$ right and 9 left ears). Mean suppression was 1.32 
Kei et al. - Ipsilateral suppression of transient evoked...

Table 2. Results of post hoc multiple comparisons of TEOAE amplitudes across frequencies. Significant differences $(p<0.05)$ are marked with an asterisk; insignificant differences are marked with a dash

\begin{tabular}{|c|c|c|c|c|c|c|c|c|c|c|c|c|c|c|c|c|c|c|c|c|c|c|c|}
\hline $\begin{array}{c}\text { Frequency } \\
(\mathrm{Hz})\end{array}$ & 586 & 781 & 977 & 1172 & 1367 & 1563 & 1758 & 1953 & 2148 & 2344 & 2599 & 2734 & 2930 & 3125 & 3320 & 3516 & 3711 & 3906 & 4102 & 4297 & 4492 & 4688 & 4883 \\
\hline 586 & & * & * & * & * & * & - & - & - & - & - & - & - & - & * & * & * & * & * & * & * & * & * \\
\hline 781 & & & * & - & - & - & - & - & - & - & - & - & * & * & * & * & * & * & * & * & * & * & * \\
\hline 977 & & & & - & - & - & - & - & - & - & - & * & * & * & * & * & * & * & * & * & * & * & * \\
\hline 1172 & & & & & - & - & * & * & - & - & - & * & * & * & * & * & * & * & * & * & * & * & * \\
\hline 1367 & & & & & & - & * & * & - & - & - & * & * & * & * & * & * & * & * & * & * & * & * \\
\hline 1563 & & & & & & & * & - & - & - & - & - & * & * & * & * & * & * & * & * & * & * & * \\
\hline 1758 & & & & & & & & - & - & - & - & - & - & * & * & * & * & * & $\star$ & * & * & * & * \\
\hline 1953 & & & & & & & & & - & - & - & - & - & * & * & * & * & * & * & * & * & * & * \\
\hline 2148 & & & & & & & & & & - & - & - & - & * & * & * & * & * & * & * & * & * & * \\
\hline 2344 & & & & & & & & & & & - & - & - & * & * & * & * & * & * & * & * & * & * \\
\hline 2599 & & & & & & & & & & & & - & - & * & * & * & * & * & * & * & * & * & * \\
\hline 2734 & & & & & & & & & & & & & - & * & * & * & * & * & * & * & * & * & * \\
\hline 2930 & & & & & & & & & & & & & & * & * & * & * & * & * & * & * & * & * \\
\hline 3125 & & & & & & & & & & & & & & & * & * & * & * & * & * & * & * & * \\
\hline 3320 & & & & & & & & & & & & & & & & - & - & - & - & * & $*$ & * & * \\
\hline 3516 & & & & & & & & & & & & & & & & & - & - & - & - & * & * & * \\
\hline 3711 & & & & & & & & & & & & & & & & & & - & - & - & - & - & * \\
\hline 3906 & & & & & & & & & & & & & & & & & & & - & - & - & - & - \\
\hline 4102 & & & & & & & & & & & & & & & & & & & & - & - & - & $\star$ \\
\hline 4297 & & & & & & & & & & & & & & & & & & & & & - & - & - \\
\hline 4492 & & & & & & & & & & & & & & & & & & & & & & - & - \\
\hline 4688 & & & & & & & & & & & & & & & & & & & & & & & - \\
\hline 4883 & & & & & & & & & & & & & & & & & & & & & & & \\
\hline
\end{tabular}

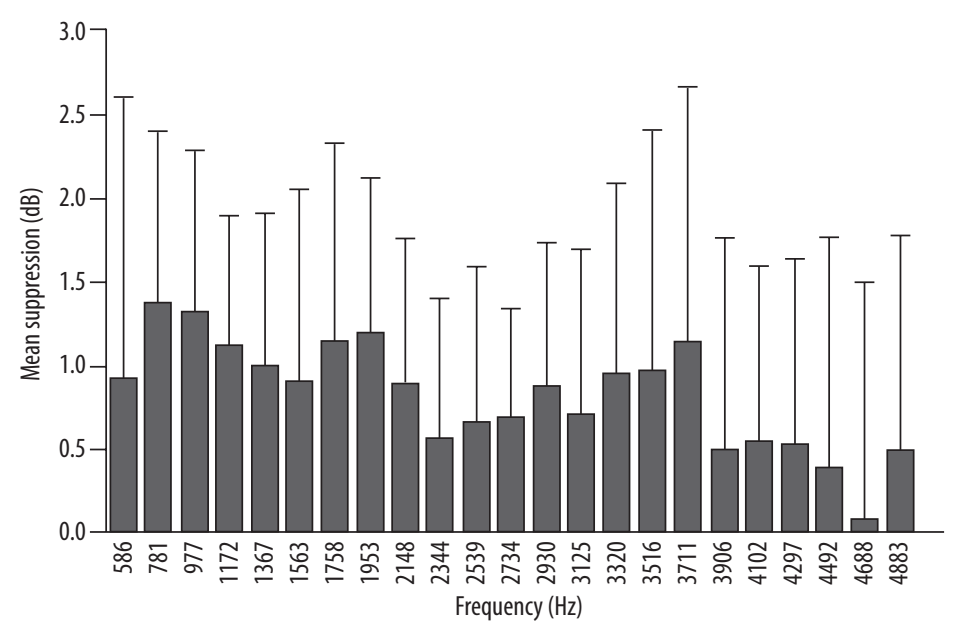

Figure 3. Mean suppression (in $\mathrm{dB}$ ) at 23 frequencies between 586 and $4883 \mathrm{~Hz}$ obtained from 29 normally hearing adults. The error bars represents 1 SD from the mean

$\mathrm{dB}$ (SD 0.71 dB; range 0.22-3.23 dB). A one-way ANOVA was applied to the suppression data with gender and ear as independent variables. The results showed no significant ear effect $[F(15,1)=0.602, p=0.45]$, no significant gender effect $[F(15,1)=1.245, p=0.282]$, and no significant Ear $\times$ Gender interaction $[F(15,1)=2.718, p=0.12]$.
To investigate TEOAE suppression as a function of time, suppression amplitude was measured from 3 to $19 \mathrm{~ms}$ in intervals of $2 \mathrm{~ms}$, and the mean results for the 29 subjects are shown in Table 3. As evident, the mean suppression increased rapidly from 2 to $8 \mathrm{~ms}$, and then stayed at an elevated level (greater than $1 \mathrm{~dB}$ ). The greatest suppression occurred at 16-18 ms, and then decreased slightly. Because 
Table 3. Mean and standard deviations of TEOAE suppression obtained from 29 normally hearing adults

\begin{tabular}{cccc}
\hline Time window $(\mathbf{m s})$ & Mean suppression $(\mathbf{d B})$ & Standard deviation $(\mathbf{d B})$ & Range $(\mathbf{d B})$ \\
\hline $2-4$ & 0.10 & 0.73 & -1.54 to 1.55 \\
\hline $4-6$ & 0.30 & 0.64 & -1.75 to 1.40 \\
\hline $6-8$ & 0.89 & 0.99 & -1.71 to 4.04 \\
\hline $8-10$ & 1.09 & 1.07 & -1.41 to 3.11 \\
\hline $10-12$ & 1.15 & 1.21 & -1.83 to 4.62 \\
\hline $12-14$ & 1.10 & 1.21 & -1.08 to 3.70 \\
\hline $14-16$ & 1.69 & 1.39 & -1.87 to 5.51 \\
\hline $16-18$ & 2.26 & 2.13 & -1.48 to 6.78 \\
\hline $18-20$ & 1.56 & 2.60 & -3.59 to 7.86 \\
\hline
\end{tabular}

Table 4. Results of post hoc multiple comparisons of TEOAE suppression across time windows. Significant differences $(p<0.05)$ are marked with an asterisk; insignificant differences are marked with a dash

\begin{tabular}{|c|c|c|c|c|c|c|c|c|c|}
\hline Time window (ms) & $2-4$ & $4-6$ & $6-8$ & $8-10$ & $10-12$ & $12-14$ & $14-16$ & $16-18$ & $18-20$ \\
\hline $2-4$ & & - & - & * & * & * & * & * & - \\
\hline $4-6$ & & & - & - & - & - & * & * & - \\
\hline $6-8$ & & & & - & - & - & - & - & - \\
\hline $8-10$ & & & & & - & - & - & - & - \\
\hline $10-12$ & & & & & & - & - & - & - \\
\hline $12-14$ & & & & & & & - & - & - \\
\hline $14-16$ & & & & & & & & - & - \\
\hline $16-18$ & & & & & & & & & - \\
\hline $18-20$ & & & & & & & & & \\
\hline
\end{tabular}

the ILO88 applies a Hamming window function on the TEOAE recordings (suppressing responses before $2.5 \mathrm{~ms}$ to eliminate stimulus ringing and again from $18.5-20.5 \mathrm{~ms}$ to reduce noise), the results obtained within the first and last intervals might not be accurate.

To compare the size of the suppression effect across time, an ANOVA with repeated measures was conducted using TEOAE suppression as the dependent variable and time window (each of the nine 2-ms windows), ear (left/right), and gender as independent variables. The G-G [26] approach was again used to compensate for violation of compound symmetry and sphericity. The results revealed a significant main effect for the time window $[F(4,200)=7.046$, $p<0.001]$, with an observed power of 0.993 . No significant ear or gender effect, or its interaction with time window, was observed $(p>0.05)$. A post hoc multiple comparisons test with Bonferroni adjustment was performed. The results, shown in Table 4, indicate significant differences in TEOAE suppression across time windows. Essentially, the mean suppression values within the 2-4 ms and 4-6 ms time windows were significantly smaller in comparison to those within other time windows.

\section{Effect of noise on suppression}

In measuring TEOAEs, noise was a possible confounding factor and difficult to assess. The noise, measured in the ear canal during testing under the forward-masking condition, varied from person to person. This noise level was the average in $\mathrm{dB}$ SPL detected by the microphone during samples which were not rejected by the ILO88 software [27]. Two noise measures were used for further analyses: Noise $_{\text {wo }}$ was the average of the noise for the two tests under the without-noise condition and Noise ${ }_{w}$ was the average of the noise for the two tests under the withnoise condition. There was no significant difference be-

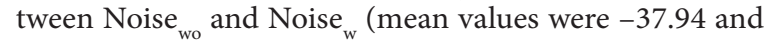
$-37.99 \mathrm{~dB}$, respectively). When an ANOVA with repeated measures was applied to the noise data with gender and ear as independent variables there were no significant main effects for noise, gender, and ear, or their interactions. A 2-tailed Pearson correlation test between Noise $_{\text {wo }}$ and Noise ${ }_{w}$ showed that the two variables were highly correlated $[\rho=0.933, p<0.0001, N=29]$. In view of these results, Noise ${ }_{\text {wo }}$ and Noise ${ }_{w}$ were averaged to form a new variable Noise $_{\text {av }}$. 
Kei et al. - Ipsilateral suppression of transient evoked...

Table 5. Results of Pearson correlation between Noise $_{a v}$ and suppression obtained at various time windows from 29 normally hearing adults

\begin{tabular}{ccc}
\hline $\begin{array}{c}\text { Time windows } \\
(\mathbf{m s})\end{array}$ & $\begin{array}{c}\text { Pearson } \\
\text { correlation }\end{array}$ & $\begin{array}{c}\text { Significance } \\
\text { (2-tailed) }\end{array}$ \\
\hline $2-4$ & 0.221 & 0.250 \\
\hline $4-6$ & 0.187 & 0.333 \\
\hline $6-8$ & -0.288 & 0.130 \\
\hline $8-10$ & 0.021 & 0.915 \\
\hline $10-12$ & -0.193 & 0.316 \\
\hline $12-14$ & -0.518 & $* 0.004$ \\
\hline $14-16$ & -0.318 & 0.093 \\
\hline $16-18$ & 0.052 & 0.789 \\
\hline $18-20$ & -0.099 & 0.611 \\
\hline
\end{tabular}

Correlations with $p<0.05$ are marked with an asterisk.

To investigate the effect of noise on suppression, a 2-tailed Pearson correlation test was applied between Noise ${ }_{\text {av }}$ and suppression at each of the time windows. The results are summarized in Table 5. Noise was found to significantly correlate with suppression within the 12-14 ms time window ( $\rho=-0.518, p=0.004)$, indicating that TEOAE suppression decreased with increasing noise level in the ear canal. Negative correlation coefficients, though not significant, were observed at time windows of $6-8,10-12,12-14$, 14-16, and 18-20 ms. Further analysis to determine the relationship between Noise ${ }_{\text {av }}$ and the average suppression across the entire $8-18 \mathrm{~ms}$ time window using a 2 -tailed Pearson correlation test showed an insignificant negative correlation $(\rho=-0.251, p=0.299, N=19)$.

Investigation into the relationship between Noise ${ }_{\text {av }}$ and suppression at different frequencies was conducted using a 2 -tailed Pearson correlation test. The results, shown in Table 6, showed significant negative correlations at $2148 \mathrm{~Hz}$ and $2344 \mathrm{~Hz}$ ( $\rho=-0.404, p=0.03$, and $\rho=-0.393, p=0.035$, respectively), and significant positive correlation at $3711 \mathrm{~Hz}$ $(\rho=0.382, p=0.041)$. The general pattern of results showed low negative correlations from $586 \mathrm{~Hz}$ to $2539 \mathrm{~Hz}$, except for $977 \mathrm{~Hz}$, and low positive correlations from $2734 \mathrm{~Hz}$ to $4883 \mathrm{~Hz}$, except for 3320, 4102, and $4688 \mathrm{~Hz}$.

\section{Discussion}

The primary aim of the present study was to investigate the characteristics of ipsilateral suppression of TEOAEs obtained from normally hearing adults using a forwardmasking paradigm. Previous studies investigating ipsilateral suppression of TEOAEs usually found the largest suppression amplitudes between 8 and $18 \mathrm{~ms}$, although they were for small sample sizes. The present investigation is the first to analyze suppression effect in both the time and frequency domains.

The TEOAE spectra for the two conditions indicate fairly robust TEOAE amplitudes exceeding $-9 \mathrm{~dB}$ SPL from 781 to $2734 \mathrm{~Hz}$. Beyond $2734 \mathrm{~Hz}$, the amplitude decreased
Table 6. Pearson correlations between Noise $\mathrm{av}_{\mathrm{av}}$ and suppression obtained at 23 frequencies from 29 normally hearing adults

\begin{tabular}{|c|c|c|}
\hline Frequency $(\mathrm{Hz})$ & $\begin{array}{l}\text { Pearson } \\
\text { correlation }\end{array}$ & $\begin{array}{l}\text { Significance } \\
\text { (2-tailed) }\end{array}$ \\
\hline 586 & -0.299 & 0.163 \\
\hline 781 & -0.308 & 0.104 \\
\hline 977 & 0.327 & 0.083 \\
\hline 1172 & -0.115 & 0.551 \\
\hline 1367 & -0.226 & 0.238 \\
\hline 1563 & -0.278 & 0.144 \\
\hline 1758 & -0.253 & 0.186 \\
\hline 1953 & -0.270 & 0.156 \\
\hline 2148 & -0.404 & *0.030 \\
\hline 2344 & -0.393 & ${ }^{*} 0.035$ \\
\hline 2539 & -0.245 & 0.201 \\
\hline 2734 & 0.082 & 0.673 \\
\hline 2930 & 0.106 & 0.584 \\
\hline 3125 & 0.072 & 0.710 \\
\hline 3320 & -0.067 & 0.729 \\
\hline 3516 & 0.207 & 0.282 \\
\hline 3711 & 0.382 & ${ }^{*} 0.041$ \\
\hline 3906 & 0.090 & 0.643 \\
\hline 4102 & -0.273 & 0.152 \\
\hline 4297 & 0.161 & 0.404 \\
\hline 4492 & 0.055 & 0.776 \\
\hline 4688 & -0.123 & 0.524 \\
\hline 4883 & 0.067 & 0.729 \\
\hline
\end{tabular}

rapidly to below $-24 \mathrm{~dB}$ SPL at $4883 \mathrm{~Hz}$ (Table 1). Further examination of the TEOAE data revealed large and comparable standard deviations for both without-noise and with-noise conditions. This indicates that the TEOAE amplitudes were quite variable between subjects. However, the variability of TEOAE amplitudes was about the same for the two test conditions.

The present study found significant differences in TEOAE amplitude across frequencies between the without-noise (A) and with-noise (B) conditions (see Table 1). Despite the small differences in mean TEOAE amplitude (which varied from 0.08 to $1.37 \mathrm{~dB}$ across frequencies from 586 to $4883 \mathrm{~Hz}$ ), these results provide clear evidence of TEOAE suppression at all frequencies between 781 and $3711 \mathrm{~Hz}$.

The study found that mean suppression varied significantly with frequency, with a maximum suppression of $1.37 \mathrm{~dB}$ at $781 \mathrm{~Hz}$ and minimum suppression of $0.08 \mathrm{~dB}$ at 4688 
$\mathrm{Hz}$ (Figure 3). The overall pattern of suppression showed greater suppression at frequencies between 586 and 3711 $\mathrm{Hz}$ than at higher frequencies $(\geq 3906 \mathrm{~Hz})$. This trend of greater suppression at low and mid frequencies, but not high frequency, was observed by Collet et al. [22], Hood et al. [9], and Veuillet et al. [17] in their studies of TEOAE suppression using a contralateral suppressor. The findings of the present study agree with those of Velenovsky and Glattke [28] who found that the strongest suppression occurred between 1 and $4 \mathrm{kHz}$. They suggested that this region of the cochlea is more sensitive to sound or there may be stronger efferent control due to a high density of MOC efferent innervation in this region.

When suppression was measured within the 8-18 ms time window, as suggested by Hood et al. [13,25], the mean suppression was $1.32 \mathrm{~dB}$. This value was greater than the 0.9 $\mathrm{dB}$ obtained by Berlin et al. [12] and $0.5 \mathrm{~dB}$ obtained by Tavartkiladze et al. [29], but smaller than the $2.4 \mathrm{~dB}$ obtained by Hood et al. [13]. The discrepancies may be due to individual differences between participants. In addition, there are differences in sample size between the present and the other studies, and the present study used a larger sample size than previous studies although it used the same protocols and recording paradigms.

The magnitude of TEOAE suppression was found to vary significantly across windows, with maximum mean suppression of $2.26 \mathrm{~dB}$ in the $16-18 \mathrm{~ms}$ window and a minimum of $0.1 \mathrm{~dB}$ in the $2-4 \mathrm{~ms}$ window and another minimum of $0.3 \mathrm{~dB}$ in the $4-6 \mathrm{~ms}$ window. Other suppression studies have also found variation in suppression values across time windows. For example, Berlin et al. [12] found that the greatest suppression effect occurred at 18-20 ms, with the least in the $2-8 \mathrm{~ms}$ window. Although these results do not reproduce those of the present study, both indicate a trend of increasing suppression with time. These results need to be interpreted with caution because the TEOAE suppression amplitudes measured at 2-4 ms and 18.5-20.5 ms might not be accurate due to the Hamming windowing introduced by the ILO88 device. The low suppression recorded during the early windows corresponds to minimal suppression at high frequencies $(\geq 3906 \mathrm{~Hz})$, as reported in the Results. In contrast, the greater suppression recorded in the later windows $(8-20 \mathrm{~ms})$ conforms with a greater suppression in the frequency range of 586-3711 $\mathrm{Hz}$, not higher frequencies $(>3711 \mathrm{~Hz})$.

The present study revealed that TEOAE suppression as a function of time could be influenced by noise in the ear canal. This effect has not been reported by previous studies. A significant moderate negative correlation $(\rho=-0.518$, $p=0.004$ ) was observed between noise and suppression in the $12-14 \mathrm{~ms}$ time window, indicating that TEOAE suppression decreased with increasing noise levels (see Table 5). These results suggest that ambient and physiological noise should be minimized in order to reduce its effect on TEOAE suppression. These results may have important clinical implications, either in terms of measuring TEOAE suppression for screening purposes or as a prospective clinical tool. As noise is a possible confounding factor in measuring TEOAE suppression, caution should be made in interpreting TEOAE data, especially when comparing suppression between two subject groups with different physiological and ambient noise levels.

The effect of noise on suppression at various frequencies was also investigated. Interestingly, the results showed a trend of weak to moderate negative correlations in the lower frequency range of 586 to $2539 \mathrm{~Hz}$ (except for $977 \mathrm{~Hz}$ ) and a trend of weak positive correlations in the higher frequency range of 2734 to $4883 \mathrm{~Hz}$ (except for 3320, 4102, and $4688 \mathrm{~Hz}$ ) (Table 6). In particular, there were significant negative correlations at 2148 and $2344 \mathrm{~Hz}$, indicating that suppression decreased as noise in the ear canal increased. These results may have implications for the effect of noise on the TEOAE suppression spectrum. Noise in the ear canal which has dominant spectral components between 586 to $2539 \mathrm{~Hz}$ could have an effect of reducing suppression. In contrast, an opposite effect was observed at higher frequencies, from 2734 to $4883 \mathrm{~Hz}$, such that an increase in noise resulted in an increase in suppression (especially at $3711 \mathrm{~Hz}$ where suppression reached a maximum of $1.14 \mathrm{~dB}$ ). The reasons for this phenomenon are unclear; it is possible that noise in the ear canal and noise from the suppressor have different effects on the basilar membrane.

The results showed no significance in suppression between the genders, despite the fact that females have been found to exhibit greater TEOAEs than males [30]. Perhaps the difference in TEOAE suppression between genders was too small to be of statistical and clinical significance. The present study did not find any significant difference in suppression between the ears, although right ears appeared to produce greater suppression than the left $(0.91 \mathrm{~dB}$ versus $0.71 \mathrm{~dB}$ ). Future studies using a larger sample size are needed to confirm this effect.

\section{Conclusions}

The present study has provided evidence of ipsilateral TEOAE suppression in the time and frequency domains using a forward-masking paradigm in a group of normally hearing adults. The mean suppression measured within the $8-18 \mathrm{~ms}$ time window was $1.32 \mathrm{~dB}$. The amount of TEOAE suppression varied depending on the time window and analysis frequency. No significant gender or ear effect was observed. Noise in the ear canal was found to have a significant effect on suppression, with increased level of noise resulting in reduced suppression at particular frequencies between 586 and $2539 \mathrm{~Hz}$ and enhanced suppression at frequencies between 2734 and $4883 \mathrm{~Hz}$. Therefore, future studies may benefit from implementing measures to reduce noise levels. Overall, this study has contributed to the limited body of research on ipsilateral suppression of TEOAEs in adults using a forward-masking paradigm.

\section{Acknowledgements}

The authors thank Professor Linda Hood (Honorary Professor 2009-15) for guidance and assistance in this research.

\section{Abbreviations}

ANOVA - Analysis of variance; BBN - Broadband noise; 
MOC - Medial olivocochlear;

OAE - Otoacoustic emission;

$\mathrm{OHC}$ - Outer hair cell;
SD - Standard deviation;

SNR - Signal-to-noise ratio;

TEOAE - Transient evoked otoacoustic emission.

\section{References:}

1. Kemp DT. Stimulated acoustic emissions from within the human auditory system. J Acoust Soc Am, 1978; 63: 1386-91.

2. Dhar S, Hall JW. Otoacoustic emissions: Principles, procedures, and protocols. San Diego: Plural Publishing; 2012.

3. Shera CA. Mammalian spontaneous otoacoustic emissions are amplitude-stabilized cochlear standing waves. J Acoust Soc Am, 2003; 114: 244-62.

4. Shera CA, Guinan JJ. Evoked otoacoustic emissions arise by two fundamentally different mechanisms: A taxonomy for mammalian OAEs. J Acoust Soc Am, 1999; 105: 782-98.

5. Guinan JJ. Olivocochlear efferents: Anatomy, physiology, function, and the measurement of efferent effects in humans. Ear Hear, 2006; 27: 589-607.

6. Berlin CI, Hood LJ, Wen H, Szabo P, Cecola RP, Rigby P et al. Contralateral suppression of non-linear click-evoked otoacoustic emissions. Hear Res, 1993;71: 1-11.

7. Dewey J, Dhar S. Medial olivocochlear influence on stimulus-frequency otoacoustic emission input-output functions. J Acoust Soc Am, 2012; 131: 3518.

8. Garinis AC, Glattke T, Cone-Wesson BK. The MOC reflex during active listening to speech. J Sp Lang Hear Res, 2008; 54: 1464-76.

9. Hood LJ, Berlin CI, Hurley A, Cecola RP, Bell B. Contralateral suppression of transient-evoked otoacoustic emissions in humans: intensity effects. Hear Res, 1996; 101: 113-18.

10. Mishra SK, Lutman ME. Repeatability of click-evoked otoacoustic emission-based medial olivocochlear efferent assay. Ear Hear, 2013: 34: 789-798.

11. Smith SB, Cone B. The medial olivocochlear reflex in children during active listening. Int J Audiol, 2015; 54(8): 518-23.

12. Berlin CI, Hood LJ, Hurley AE, Wen AH, Kemp DT. Binaural noise suppresses linear click-evoked otoacoustic emissions more than ipsilateral or contralateral noise. Hear Res, 1995;87: 96-103.

13. Hood LJ, Berlin CI, Bordelon J, Rose K. Patients with auditory neuropathy/dys-synchrony lack efferent suppression of transient evoked otoacoustic emissions. J Am Acad Audiol, 2003; 14: $302-13$.

14. Muchnik C, Ari-Even Roth D, Othman-Jebara R, Putter-Katz H, Shabtai EL, Hildesheimer M. Reduced medial olivocochlear bundle system function in children with auditory processing disorders. Audiol Neurotol, 2004; 9: 107-14.

15. Maurer J, Beck A, Mann W, Mintert R. Changes in otoacoustic emissions with simultaneous acoustic stimulation of the contralateral ear in normal probands and patients with unilateral acoustic neurinoma. Laryngo-rhino-otologie, 1992; 71: 6973 (Article in German).

16. Pracher D, Ryan S, Luxon L. Contralateral suppression of transient otoacoustic emissions and neuro-otology. Brit J Audiol, 1994; 28: 247-54.
17. Veuillet E, Collet L, Duclaux R. Effect of contralateral acoustic stimulation on active cochlear micromechanical properties in human subjects: dependence on stimulus variables. J Neurophysiol, 1991;65: 724-35.

18. Berlin CI, Goforth-Barter L, Hood LJ. Some hyperacusics show abnormally strong efferent suppression of TEOAEs. Association for Research in Otolaryngology Conference Abstract, 1998; 15: 117.

19. Roup CM, Wiley TL, Safady SH, Stoppenbach DT. Tympanometric screening norms for adults. Am J Audiol, 1998; 7: 55-60.

20. Wiley TL, Oviatt DL, Block MG. Acoustic-immittance measures in normal ears. J Speech Hear Res, 1987; 30: 161-70.

21. Kei J, Sockalingam R, Holloway C, Agyik A, Brinin C, Baine D. Transient evoked otoacoustic emissions in adults: a comparison between two test protocols. J Am Acad Audiol, 2003;14: 563-73.

22. Collet L, Kemp DT, Veuillet E, Duclaux R, Moulin A, Morgon A. Effect of contralateral auditory stimuli on active cochlear micro-mechanical properties in human subjects. Hear Res, 1990;43: 251-62.

23. Hood LJ, Berlin CI, Wakefield L, Hurley A. Noise duration affects bilateral, ipsilateral and contralateral suppression of transient-evoked otoacoustic emissions in humans. Association for Research in Otolaryngology Conference Abstract, 1995; 19: 123 .

24. Wen H, Berlin CI, Hood LJ, Jackson DF, Hurley A. A program for quantification and analysis of transient evoked otoacoustic emissions. Association for Research in Otolaryngology Conference Abstract, 1993; 16: 102.

25. Hood LJ. Suppression of otoacoustic emissions in normal individuals and in patients with auditory disorders. In: Robinette MS, Glattke TJ, editors. Otoacoustic Emissions: Clinical applications. $2^{\text {nd }}$ ed. New York: Thieme; 2002; 325-47.

26. Greenhouse SW, Geisser S. On the methods in the analysis of profile data. Psychometrika, 1959; 24: 95-112.

27. Glattke TJ, Robinette MS. Transient evoked otoacoustic emissions. In: Robinette MS, Glattke TJ, editors. Otoacoustic Emissions: Clinical applications. $3^{\text {rd }}$ ed. New York: Thieme; 2007; 63-82.

28. Velenovsky DS, Glattke TJ. Contralateral and binaural suppression of otoacoustic emissions. In: Robinette MS, Glattke TJ, editors. Otoacoustic Emissions: Clinical applications. $2^{\text {nd }}$ ed. New York: Thieme; 2002; 163-89.

29. Tavartkiladze GA, Frolenkov GI, Artamasov SV. Ipsilateral suppression of transient evoked otoacoustic emission: role of the medial olivocochlear system. Acta Otolaryngol, 1996; 116: 213-18.

30. Robinette MS. Clinical observations with evoked otoacoustic emissions at Mayo Clinic. J Am Acad Audiol, 2003; 14: 213-24. 